\section{Students' Conception of Genetic Phenomena and Its Effect on Their Ability to Understand the Underlying Mechanism}

Michal Haskel-Ittah* and Anat Yarden

Department of Science Teaching, Weizmann Institute of Science, Rehovot 76100, Israel

\begin{abstract}
Understanding genetic mechanisms affords the ability to provide causal explanations for genetic phenomena. These mechanisms are difficult to teach and learn. It has been shown that students sometimes conceive of genes as traits or as trait-bearing particles. We termed these "nonmechanistic" conceptions of genetic phenomena because they do not allow the space required for a mechanism to exist in the learner's mind. In this study, we investigated how ninth- and 12th-grade students' conceptions of genetic phenomena affect their ability to learn the underlying mechanisms. We found that ninth- and 12th-grade students with nonmechanistic conceptions are less successful at learning the mechanisms leading from gene to trait than students with mechanistic conceptions. Our results suggest that nonmechanistic conceptions of a phenomenon may create a barrier to learning the underlying mechanism. These findings suggest that an initial description of a phenomenon should hint at a mechanism even if the mechanism would be learned only later.
\end{abstract}

\section{INTRODUCTION}

Mechanisms are central to understanding and describing how phenomena are generated. Scientists use mechanisms to explain, predict, and control natural phenomena (Craver and Darden, 2013). In science education, there has been a focus on promoting mechanistic explanations over teleological and anthropomorphic ones (Tamir and Zohar, 1991; Abrams and Southerland, 2001). The importance of mechanistic reasoning lies in its use to suggest mechanisms underlying unexplored phenomena (van Mil et al., 2013).

In the past two decades, research in biology education had put much emphasis on students' understanding of genetic mechanisms (e.g., Marbach-Ad and Stavy, 2000; Stewart et al., 2005; Duncan and Tseng, 2011; Freidenreich et al., 2011; Shea et al., 2015; van Mil et al., 2016). These studies show that understanding genetic mechanisms is challenging. Specifically, students have difficulty understanding the genetic mechanisms by which genes determine traits (Lewis and Kattmann, 2004; Dos Santos et al., 2012; Gericke and Wahlberg, 2013). When referring to gene-to-trait mechanisms, we relate to the more general process leading from gene to protein production in a cell, the so-called central dogma in biology, as well as to more specific cellular mechanisms leading to the expression of different traits. The differences between these mechanisms lie in the various functions of the translated proteins (e.g., protein kinase, cellular receptor) and, accordingly, their involvement in many cellular processes leading to traits (e.g., eye color, height).

It has been shown that students of various ages often conceive of genes as passive particles passed from parents to offspring (Venville and Treagust, 1998). Even when students conceive of genes as controlling traits, they experience difficulties explaining how this occurs (Marbach-Ad and Stavy, 2000; Duncan and Reiser, 2007; Todd and Kenyon, 2015).

High-school students struggle with explaining what genes are (Marbach-Ad and Stavy, 2000). Similarly, students often use explanations that imply that genes are traits
Rachelle Spell Monitoring Editor

Submitted Jan 23, 2018; Revised Apr 3, 2018; Accepted Apr 10, 2018

CBE Life Sci Educ September 1, 2018 17:ar36 DOI:10.1187/cbe.18-01-0014

*Address correspondence to: Michal Haskel-Ittah (Haskel(aweizmann.ac.il).

(C) 2018 M. Haskel-Ittah and A. Yarden. CBE-Life Sciences Education @ 2018 The American Society for Cell Biology. This article is distributed by The American Society for Cell Biology under license from the author(s). It is available to the public under an Attribution-Noncommercial-Share Alike 3.0 Unported Creative Commons License (http://creativecommons.org/licenses/ by-nc-sa/3.0)

"ASCB®" and "The American Society for Cell Biology ${ }^{\prime \prime}$ are registered trademarks of The American Society for Cell Biology. 
or carry traits (Lewis and Kattmann, 2004; Venville et al., 2005). These alternative conceptions of genes were suggested to stem from using the terms "genes" and "traits" interchangeably (Thörne et al., 2013). Conceiving of genes as traits or as carriers of traits could be educationally problematic, because this view may abolish the need for a mechanism; as such, it may form a barrier to learning about possible mediating mechanisms (Lewis and Kattmann, 2004; Venville et al., 2005; Southard et al., 2016).

Although many studies have characterized the difficulties experienced by students in understanding the mechanisms by which genes determine traits and have focused on improving instruction, less attention has been paid to the origin of the differences in students' gains from such instruction-the reason some students fail to understand these mechanisms, while others succeed with the same instruction. As already noted, conceiving of genes as traits, or as trait-bearing particles, is suggested to hamper the learning of the mechanisms by which genes affect traits, because these alternative conceptions abolish the need for such mechanisms in the learner's mind.

During our evaluation of students' understanding of the mechanisms underlying genetic phenomena, we frequently identified the aforementioned alternative conceptions. We were interested in assessing how these conceptions might affect students' understanding of the underlying mechanisms. Assessing the relationship between students' conceptions of genetic phenomena and their ability to understand genetic mechanisms may shed light on the origin of students' difficulties in this field: Is it only the objective, an intrinsic difficulty of the domain, or does it also have a subjective origin that is dependent on students' conception of genetics?

In this study, we investigated how ninth- and 12th-grade students' conceptions of genetic phenomena, namely, their understanding of the relationship between genes and traits, affect their ability to learn the mechanisms underlying genetic phenomena. Specifically, we asked,

1. What is the prevalence of alternative conceptions of the relationship between genes and traits among ninth-grade students who have not yet learned genetics in school?

2. Do these possible alternative conceptions affect learning the gene-to-trait mechanisms in high school, and how?

\section{THEORETICAL FRAMEWORK}

\section{Difficulties in Understanding Genetic Mechanisms}

In biology, the importance of molecular mechanistic reasoning lies in its use to generate ideas and hypotheses about the mechanisms underlying unexplored biological phenomena (van Mil et al., 2013). In the field of genetics, explanatory models of classical genetics extend into the realm of the cellular and molecular mechanisms underlying patterns of inheritance. The ability to provide a causal explanation for genetic phenomena is limited without an understanding of these mechanisms (Stewart et al., 2005; Duncan and Reiser, 2007). In addition, knowledge about the mechanisms by which genes determine traits allows understanding the hierarchy of biological processes through which the environment can influence an organism. This understanding may prevent notions of genetic determinism (Venville et al., 2005).
Research shows that, despite its importance, understanding these mechanisms is challenging (e.g., Marbach-Ad and Stavy, 2000; Duncan and Reiser, 2007; Freidenreich et al., 2011; Haskel-Ittah and Yarden, 2017). Marbach-Ad and Stavy (2000) reported that ninth- and 12th-grade students offer explanations for organisms' traits by using the concept "gene," but cannot explain what a gene is or how it affects traits. In addition, the authors showed that students fail to grasp the connection between protein and trait. This may be the result of a limited understanding of proteins and their relationships with higher organizational levels. Thus, students are often not aware of the central roles played by proteins in biological processes, and they do not presume that biological phenomena with genetic origins are mediated by proteins.

Learning molecular genetic mechanisms is not sufficient for the understanding that these mechanisms explain genetic phenomena. Several studies have shown that students sometimes separate knowledge about the phenomena from knowledge about molecular components that take part in executing these mechanisms (Duncan and Reiser, 2007; Gericke and Wahlberg, 2013; Haskel-Ittah and Yarden, 2017). When students were asked to connect different genetic concepts, they connected genes to traits and separated these two concepts from molecular concepts, such as enzymes or proteins, which are central parts in genetic mechanisms (Marbach-Ad, 2001). Gericke and Wahlberg (2013) reported that upper secondary-level science students have distinct clusters of molecular genetic concepts and of concepts related to classical genetics. This information is in accordance with a study that indicated that novice undergraduate students form mainly nonmechanistic connections between genetic concepts, and it is only during their studies that some students move toward more functional, causal, and mechanistic connections (Southard et al., 2016). Results obtained by Southard et al. (2016), Gericke and Wahlberg (2013), and Marbach-Ad (2001) indicated that difficulties in understanding how molecular genetic mechanisms explain genetic phenomena are widespread among students of all ages.

One of the reasons for these difficulties is that the mechanisms involved are incoherently presented in textbooks and by teachers (Gericke and Hagberg, 2007; Flodin, 2009; Thörne and Gericke, 2014). For example, proteins-central entities in the gene-to-trait mechanisms-are described as the products of genes, while at the same time, the gene's role is described as affecting traits. This has been shown to be a major source of confusion that might eventually lead to the conception of genes as having two distinct roles-one being protein production and the other being trait determination (Gericke et al., 2013; Gericke and Wahlberg, 2013).

Several studies have indicated the importance of emphasizing the role of proteins as mediators between genes and traits when teaching genetic phenomena (Lewis and Kattmann, 2004; Duncan et al., 2009; Todd and Kenyon, 2015). Duncan et al. (2009) proposed a learning progression (LP) for learning genetics. This LP offers various basic ideas in genetics that should be learned progressively, starting in the fifth grade. Basic ideas are presented in the early stages of the LP, and as students move along the progression, their understanding of this complex process increases. Ideas include the dual understanding of genes as instructions for proteins and proteins as mediators between genes and traits. 
Several instructions that were built upon this LP were shown to improve, to a certain extent, students' understanding of the mechanisms by which genes determine traits. However, these studies also indicated that a nonnegligible number of students do not improve as much as others (Duncan et al., 2011; Freidenreich et al., 2011; Todd and Kenyon, 2015; Haskel-Ittah and Yarden, 2017). These findings were similar when instructions were not based on the LP (Reinagel and Speth, 2016).

\section{Learning the Underlying Mechanisms}

Mechanisms are composed of entities and activities that are organized in a specific manner. Entities are the physical parts in the mechanism, and activities are the things that the entities do (Machamer et al., 2000; Craver, 2001; Darden, 2008). Entities in a mechanism have specific properties, such as shape and orientation, which allow them to perform certain activities that will produce the change underlying the phenomenon (Boogerd et al., 2005; Craver and Darden, 2013). Thus, understanding a mechanism means understanding the characteristics of its entities, the relationship between them, and how they are organized.

For example, the mechanisms by which genes affect traits include the entities genes with specific DNA sequences, proteins with specific structures, other substances that interact with the proteins, certain kinds of cells that are affected by the proteins' activities, and so on. The relationship between these entities may be, for instance, that a gene encodes a protein or that the protein binds with another substance, affecting the cells in a certain way.

The entities and activities in a mechanism can be schematically represented by the names of the entities connected by arrows that represent activities. Craver and Darden (2013) described various potential flaws in such schemas. A schema such as $\mathrm{A} \rightarrow \mathrm{D}$, instead of $\mathrm{A} \rightarrow \mathrm{B} \rightarrow \mathrm{C} \rightarrow \mathrm{D}$, is classified as a superficial description. This representation merely describes a phenomenon and is thus termed a "phenomenal model" (Craver, 2006; Craver and Darden, 2013). Phenomenal models do not describe a mechanism; however, they do suggest a causal relationship that allows space for a mechanism to exist in the learner's mind. This means that although the schema gene $\rightarrow$ trait does not describe a mechanism, it holds the potential to discover one, thus reflecting mechanistic conception of the phenomenon. In contrast, the nonmechanistic schema derived from stating that genes are traits, which can be represented as gene $=$ trait, does not. The schema gene $=$ trait describes the phenomenon incorrectly by not allowing, and not even reflecting, the need for the existence of a mediating mechanism. A similar case is the description of genes as bearing or composed of traits, which can be described schematically as gene $\subset$ trait. This gene $\subset$ trait description, similar to the gene $=$ trait one, does not hold the potential for the existence of a mechanism, and therefore also reflects a nonmechanistic conception.

We were interested in understanding how the two cases of nonmechanistic conceptions of genetic phenomena, which we represent as gene $\subseteq$ trait, as opposed to gene $\rightarrow$ trait , might affect the learning of the underlying mechanisms. We hypothesized that such conceptions of the phenomena would affect the learning of genetic mechanisms, because in the course of learning, students form connections between new knowledge and their prior knowledge (Ausubel, 1963). The conception gene $\rightarrow$ trait may allow the integration of knowledge about entities, such as proteins, with the prior knowledge. This integration probably occurs because describing genes as affecting traits suggests a causal relationship that may be mediated by other entities. However, the conceptions gene $\subseteq$ trait may not allow this space for a mechanism, thereby preventing the integration of knowledge about entities involved in a possible underlying mechanism into these conceptions.

\section{METHODS}

The Context of the Study-the "Learning Genetics on the Fly" Environment

"Learning Genetics on the Fly" (stwww1.weizmann.ac.il/lgof) is a teaching and learning environment that is based on authentic examples from the genetics of the fruit fly, Drosophila melanogaster. This learning environment consists of a "fly lab" and computational activities. When this study was conducted, the learning activities were assimilated into the Moodle learning management system. The learning activities deal with the role of proteins in mediating the formation of traits through genes and were specifically designed to support understanding of this issue. Each activity focuses on one gene and prompts the students to construct explanations regarding the proteins encoded by specific genes as mediators between the genes and visible traits in the fly. We previously showed that use of this learning environment improves 10th-grade students' understanding of the mechanism mediating between genes and traits (HaskelIttah and Yarden, 2017).

\section{Population}

Prevalence of the nonmechanistic conception gene $\subseteq$ trait (research question 1) was characterized among 152 students in the ninth grade from three different schools. For assessment of the effect of this conception on learning genetic mechanisms (research question 2), analysis was focused on another group of ninth-grade students $(n=21)$ (who learned in two different classes taught by the same teacher) and 25 students in the 12th grade. These 12th graders were part of a group of 30 students from two different classes. We focused on only the 25 students who formed a link between the concepts "gene" and "trait." Out of these 25 students, 18 were taught by one teacher and seven by another. The ninth-grade students performed one computational activity in the environment that focused on how a certain protein is involved in a genetic mechanism. Their teacher used other examples from the learning environment to stress the central role of proteins in genetic mechanisms. The 12th graders performed two activities, each focusing on a different protein. In these activities, students were asked to explain how a specific gene and its different variations, termed "alleles," affect the fly's appearance. Posttests were administered after the activities were completed.

\section{Data Sources and Analysis}

To evaluate the prevalence of the gene $\subseteq$ trait conception among ninth-grade students, we analyzed concept maps created by the 152 students. Concept mapping is a technique for externalizing concepts and the propositions that express the relationships between concepts in the learner's mind (Novak and Gowin, 1984). Students were asked to create a concept map using eight genetic concepts that were provided to them 
TABLE 1. Examples of students' conception classifications according to their linking sentences in the concept maps

\begin{tabular}{ll}
\hline Mechanistic conception (gene $\rightarrow$ trait) & Nonmechanistic conception (gene $\subseteq$ trait) \\
\hline "A gene affects a trait." & "A gene is a trait." \\
"A gene determines a trait." & "A trait is inside the gene." \\
"A trait is the result of a gene." & "[Genes and traits are] the same thing." \\
\hline
\end{tabular}

(gene, protein, trait, chromosome, DNA, meiosis, parents, and offspring). Students were instructed to create as many connections as they could and write a linking sentence above each connecting line between two concepts. Before preparing the concept map, students learned how to build concept maps using simple concepts such as rain, water, sea, rivers, and clouds (White and Gunstone, 2014).

In this part, we focused on the connections formed by students between the concepts "gene" and "trait" in the concept maps. These connections were analyzed to classify students according to their conceptions regarding the gene-trait relationship before learning genetics. Students who formed a connection between the concepts "gene" and "trait" and used a linking sentence suggesting a causal relation (mechanistic relationship) were classified as having the mechanistic conception of gene $\rightarrow$ trait. Students who formed a connection and used a linking sentence suggesting a nonmechanistic relationship between the concepts "gene" and "trait" were classified as having the conception of gene $\subseteq$ trait (for examples, see Table 1). Students who did not form this connection were classified as "no connection." For representative concept maps, see the Supplemental Material.

To examine the effect of these conceptions on learning genetic mechanisms (research question 2), we

1. Classified students' conception of the relationships between genes and traits into gene $\rightarrow$ trait and gene $\subseteq$ trait. At the same time, we ranked students' preliminary understanding of the underlying mechanism (using a pretest that will be described later).

2. Ranked students' understanding of the underlying mechanism (using a posttest that was similar to the pretest).

3. Compared the level of mechanistic understanding among students whose conception was characterized as gene $\rightarrow$ trait at the beginning of the genetics course and students' whose conception was characterized as gene $\subseteq$ trait at the beginning of the genetics course.

Between step 1 and step 2, students used the "Learning Genetics on the Fly" environment to learn about genetic mechanisms. It should be noted that students' conceptions were only characterized at the beginning of their genetics course: we were not interested in how this conception changed over time but in how it affects students' learning abilities.

Pretests and posttests were composed of two open-ended questions and the concept maps described earlier. This test was used in another study that evaluated mechanistic understanding among 10th graders (Haskel-Ittah and Yarden, 2017). The first open-ended question (in both the pretest and posttest) was: "What are genes?" The second open-ended question had two versions:

A. Flowers of a certain plant are either red or white. Explain how genes might affect the color of the flowers.

B. A certain kind of lettuce can have either toxic leaves or edible ones. Explain how genes might affect the leaves' toxicity.
Half of the students were given version A of the second question in the pretest and version B in the posttest, and vice versa for the other half. Open-ended question 1 and concept map instructions were the same in the pretest and posttest.

As previously mentioned, classification of students' conception was done using the concept map. Analysis was focused only on students whose gene-trait conception could be classified, namely, those who formed a connection between the concepts "gene" and "trait" in the concept map. To further support our classification to gene $\rightarrow$ trait or gene $\subseteq$ trait , we analyzed students' descriptions of genes in one of the open-ended questions that appeared in the pretest ("What are genes?"). Students' conceptions that were probed using the concept map had $96 \%$ accordance with the conceptions probed using this openended question. Namely, $96 \%$ of the students who were classified as having one type of conception in the concept map described genes in the open-ended question using phrases that suggested the same type of conception (e.g., "genes determine traits," "genes carry the traits we get from our parents," or "genes are traits").

The pretest and posttest were compared to evaluate changes in students' understanding of the mechanisms by which genes affect traits. One of the basic levels of mechanistic reasoning is the ability to identify entities that are involved in the mechanism (Russ et al., 2008). All gene-to-trait mechanisms have a common central entity, which is the protein. Our analysis focused on students' understanding of proteins as central entities in this mechanism and observed whether students conceived proteins as such. We focused on proteins, because it has been previously shown that, despite their central role in all gene-to-trait mechanisms, students tend to ignore this entity or have difficulties explaining how proteins are involved in these mechanisms (Duncan and Reiser, 2007; Gericke and Hagberg, 2007; Reinagel and Speth, 2016; Haskel-Ittah and Yarden, 2017).

To assess students' understanding of the role of proteins as mediators in the mechanisms of trait determination, we analyzed students' concept maps and responses to open-ended questions. Specifically, we focused on whether students formed the gene-protein and protein-trait connections in concept maps and whether students referred to the concept of "protein" in the open-ended question. Four parameters were examined, each ranked as 1 or 0 . The total score for conceiving proteins as central entities in gene-to-trait mechanisms was the sum of these parameters. The four parameters were

1. Correctly connecting the concepts "protein" and "gene" (concept map)

2. Correctly connecting the concepts "protein" and "trait" (concept map)

3. Referring to proteins when asked what genes are (openended question 1)

4. Using proteins to explain the effect of genes on traits (openended question 2) 
As noted, only connections with a correct linking sentence were counted. For example, students who linked gene to protein and wrote "The gene encodes a protein" or "The gene contains information for protein production" were counted as correctly referring to the protein level. However, a gene-protein connection with the sentence "The gene is a protein" is a mistake and was counted as wrong. For representative concept maps, see the Supplemental Material.

The two open-ended questions asked students to explain the effect of a gene on a given plant trait. In both questions, students could either refer to proteins or not. An answer that fails to refer to the protein level is not wrong, but it ignores the mechanisms by which genes determine traits. Thus, we ranked these answers as referring to or ignoring the protein level.

Ten percent of the data were given to another researcher for validation. The agreement on the coding was $\sim 86 \%$ at the beginning and reached $100 \%$ after discussion.

\section{RESULTS \\ Prevalence of Nonmechanistic Genetic Conceptions among Ninth Graders}

We aimed to focus on how students' conceptions of genetic phenomena affect their ability to learn the mechanisms underlying those phenomena. Therefore, we first characterized these conceptions and examined their prevalence among ninth-grade students before their genetics studies. We classified the conceptions that genes are traits or bear traits as nonmechanistic conceptions of genetic phenomena and represented these as gene $\subseteq$ trait. The conception of genes as affecting or determining traits (gene $\rightarrow$ trait) was classified as a mechanistic conception of genetic phenomena because it suggests the existence of a mediating mechanism.

The ninth-grade students who were at the beginning of their first genetics course $(n=152)$ were asked to create a concept map with the different genetic concepts provided to them (see Methods). Students were instructed to create as many connections as they could and to write a linking sentence above each connecting line between two concepts. Analysis of students' concept maps revealed that $28 \%(n=42)$ of the ninth graders participating in this part of the study formed a gene $\subseteq$ trait-type connection between the concepts "gene" and "trait." These students used phrases such as "A gene is a trait" or "A trait is inside a gene" to connect the two concepts; $41 \%(n=62)$ of the students formed a gene $\rightarrow$ trait-type concept connection by indicating a causal relationship between the two (e.g., "A gene determines a trait"); $31 \%(n=48)$ of the students did not form any connection between the concepts.

These results indicate that almost one-third of the ninthgrade students examined here began their genetics education with a conception that genes are traits or are trait-bearing particles. The predominance of this nonmechanistic conception among these students encouraged us to examine its effect on understanding the mechanisms by which genes determine traits.

\section{Effect of Students' Preconceptions on Mechanistic Understanding}

According to the Israeli high school biology curriculum, students who choose to major in biology study genetics in the 12th grade in addition to the ninth grade. We were interested in analyzing the effect of the aforementioned alternative conceptions on learning the gene-to-trait mechanisms among both ninth and 12th graders. We studied a group of 30 ninth-grade students and 31 students in 12th grade. Among the ninth graders, nine students (30\%) were classified as holding a gene $\subseteq$ trait conception, 12 students (40\%) held a mechanistic gene $\rightarrow$ trait conception, and nine students (30\%) did not form a connection between gene and trait in their concept maps. Surprisingly, the proportion of students demonstrating the gene $\subseteq$ trait conception among 12th graders was the same as among the ninth graders-about one-third (nine students, 29\%); 16 students (52\%) were classified as demonstrating the gene $\rightarrow$ trait conception, and six students (19\%) had no connection between gene and trait in their concept maps. Students who did not form any connection between gene and trait were not further analyzed in this study. Following this classification of students' conceptions, we turn to a study of their understanding of the mechanisms by which genes affect traits.

Proteins constitute a central entity that is common to all gene-to-trait mechanisms. Thus, students' understanding of these mechanisms was evaluated using parameters that should reflect their understanding of proteins as central for these mechanisms to take place (see Data Sources and Analysis section in Methods). In the pretest, none of the ninth-grade students formed a connection between the concept "protein" and the concepts "gene" and "trait," and none mentioned proteins in their answers to the open-ended questions. This means that, although students had different conceptions regarding the relationships between genes and traits, they all shared the conception that proteins are not part of this relationship.

The 12th-grade students had some knowledge about proteins. Nonetheless, no significant differences in their understanding of the centrality of proteins were observed between the gene $\subseteq$ trait group and the gene $\rightarrow$ trait one.

During their genetics course, students performed activities in a computational learning environment (see The Context of the Study section in Methods). These activities were designed to foster an understanding of the mechanisms underlying the gene-trait connection. Along with these activities, the teacher combined parts of the learning environment with conventional instructional strategies for teaching genetics.

After instruction, students' conception of proteins as mediators between genes and traits was reexamined. Analyzing students' outcomes following instruction revealed striking differences between the gene $\rightarrow$ trait group and the gene $\subseteq$ trait group (Figure 1). Students' improvement from pretest to posttest was significantly higher in the gene $\rightarrow$ trait group than in the gene $\subseteq$ trait group (Wilcoxon two-sample test: ninth grade, signed rank test $[\mathrm{S}]=69.5, p<0.05$; 12 th grade, $\mathrm{S}=85, p<$ 0.05). In fact, an understanding of proteins as central entities in mediating genes and traits was significantly improved among students who were classified as having a mechanistic gene-trait conception (gene $\rightarrow$ trait group; signed-rank test: ninth grade, $\mathrm{S}$ $=18, p<0.01 ; 12$ th grade, $\mathrm{S}=32.5, p<0.01$ ). In contrast, students who were classified as having a nonmechanistic gene-trait conception (gene $\subseteq$ trait group) did not show any such improvement (ninth grade, $\mathrm{S}=0.5, p=1$; 12 th grade, $\mathrm{S}=1.5, p=0.7$ ).

Table 2 presents the relative percentages of students who succeeded in each parameter for each group in the posttest. Note again that none of the ninth-grade students knew about 

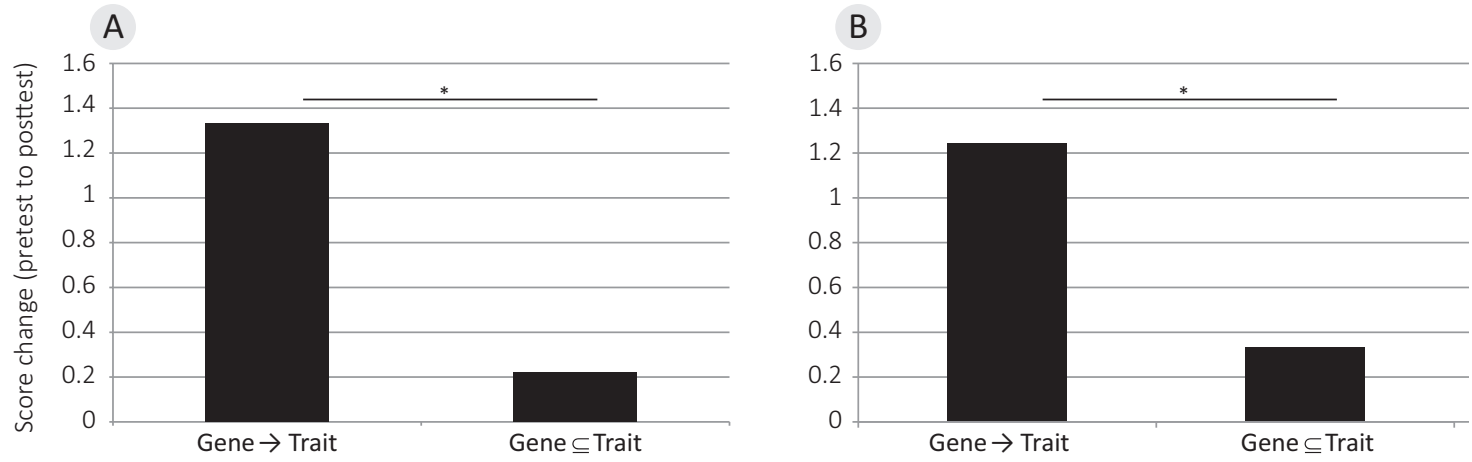

FIGURE 1. Differences in scores for ninth (A) and 12th (B) graders from pretest to posttest among students with mechanistic and nonmechanistic conceptions of the gene-trait relationship. Scores were based on the four parameters mentioned in the Methods section. (A) Ninth graders: gene $\rightarrow$ trait (mechanistic), $n=12$; gene $\subseteq$ trait (nonmechanistic), $n=9$. Wilcoxon two-sample test: $S=69.5,{ }^{*} p<0.5$, $n=21$. (B) Twelfth graders: gene $\rightarrow$ trait (mechanistic), $n=16$; gene $\subseteq$ trait (nonmechanistic), $n=9$. Wilcoxon two-sample test: $S=85$, ${ }^{*} p<0.5, n=25$.

the involvement of proteins in determining traits before learning $(0 \%$ success for all students in all protein parameters in the pretest; Table 2, left part). However, after instruction, the gene $\subseteq$ trait group outcomes were much lower than those of the gene $\rightarrow$ trait group. In fact, in the posttest, none of the gene $\subseteq$ trait group students connected gene to protein or used proteins to explain the effect of genes on plant traits. In addition, only $11 \%$ (one student, $n=9$ ) of these students connected protein to trait and referred to proteins when asked to explain what genes are (Table 2). In contrast, in the gene $\rightarrow$ trait group, more than $40 \%$ of the students (five students, $n=12$ ) connected the concepts "protein" and "gene" in the concept map; 50\% (six students, $n=12$ ) connected the concept "protein" to trait; and 33\% (four students, $n=12$ ) created the mechanism schema gene-proteintrait in their concept maps. In answer to the question "What are genes?," $25 \%$ of the gene $\rightarrow$ trait group (three students, $n=12$ ) referred to proteins, and $17 \%$ (two students, $n=12$ ) used proteins to explain how genes determine traits.

The same trend of differences between the gene $\rightarrow$ trait group and the gene $\subseteq$ trait group was observed among 12th graders (Table 2, right part); for example, in pretest concept maps, $11 \%$ of the gene $\subseteq$ trait connected protein to trait, and this was unchanged after instruction. In contrast, $12.5 \%$ of the gene $\rightarrow$ trait group formed a connection between protein and trait in the pretest, and 50\% of this group formed the proteintrait connection in the posttest. This indicates that in both ninth and 12th grades, students who were classified as having the gene $\subseteq$ trait conception, as opposed to the gene $\rightarrow$ trait conception, did not gain understanding of the central role of proteins.

To address the possibility that the two groups differ in their overall biological capabilities and not specifically in parameters that relate to understanding the mechanisms by which genes affect traits, we analyzed the students' connections between the concepts "gene" and "chromosome" in their pre- and posttest concept maps. The "chromosome" concept and the fact that it contains genes was studied before these students' genetics studies as part of learning the subject of reproduction. This chromosome-gene connection is a structural one and was not expected to be influenced by alternative conceptions regarding the connections between genes and traits; it does not contradict the alternative conception that genes are or contain traits, and thus it may be integrated with knowledge about genetics regardless of whether a nonmechanistic or mechanistic conception exists. Results of both groups were very similar, with no significant difference being observed in the pretest or posttest (chi-square test: ninth grade, pretest $\chi^{2}=0.17, p=0.7$, posttest $\chi^{2}=0.66$,

TABLE 2. Ability of ninth and 12th graders with different conceptions of gene-trait relationships to understand the protein's role in the mediating mechanism, before and after instruction

\begin{tabular}{|c|c|c|c|c|c|c|c|c|}
\hline & \multicolumn{4}{|c|}{ Ninth grade: Percentage out of each group } & \multicolumn{4}{|c|}{ 12th grade: Percentage out of each group } \\
\hline & \multicolumn{2}{|c|}{ Pretest } & \multicolumn{2}{|c|}{ Posttest } & \multicolumn{2}{|c|}{ Pretest } & \multicolumn{2}{|c|}{ Posttest } \\
\hline & $\begin{array}{c}\text { Group: } \\
\text { gene } \subseteq \text { trait } \\
(n=9)\end{array}$ & $\begin{array}{c}\text { Group: } \\
\text { gene } \rightarrow \text { trait } \\
(n=12)\end{array}$ & $\begin{array}{c}\text { Group: } \\
\text { gene } \subseteq \text { trait } \\
(n=9)\end{array}$ & $\begin{array}{c}\text { Group: } \\
\text { gene } \rightarrow \text { trait } \\
(n=12)\end{array}$ & $\begin{array}{c}\text { Group: } \\
\text { gene } \subseteq \text { trait } \\
(n=9)\end{array}$ & $\begin{array}{c}\text { Group: } \\
\text { gene } \rightarrow \text { trait } \\
(n=16)\end{array}$ & $\begin{array}{c}\text { Group: } \\
\text { gene } \subseteq \text { trait } \\
(n=9)\end{array}$ & $\begin{array}{c}\text { Group: } \\
\text { gene } \rightarrow \text { trait } \\
(n=16)\end{array}$ \\
\hline $\begin{array}{l}\text { Gene-protein connection in } \\
\text { concept map }\end{array}$ & 0 & 0 & 0 & 42 & 0 & 25 & 11 & 62.5 \\
\hline $\begin{array}{l}\text { Protein-trait connection in } \\
\text { concept map }\end{array}$ & 0 & 0 & 11 & 50 & 11 & 12.5 & 11 & 50 \\
\hline $\begin{array}{l}\text { Referring to proteins when } \\
\text { asked what genes are }\end{array}$ & 0 & 0 & 11 & 25 & 11 & 18.7 & 22 & 37.5 \\
\hline $\begin{array}{l}\text { Using proteins to explain the } \\
\text { effect of genes on a } \\
\text { plant's trait }\end{array}$ & 0 & 0 & 0 & 17 & 11 & 12.5 & 22 & 43 \\
\hline
\end{tabular}


$p=0.8,12$ th grade, pretest $\chi^{2}=1.2, p=0.25$, posttest $\chi^{2}=1.8$, $p=0.16$ ). This means that the gene $\subseteq$ trait and gene $\rightarrow$ trait groups had similar abilities with respect to making a structural connection between gene and chromosome, as expected.

These data suggest that the nature of students' conceptions regarding the relationship between genes and traits before their genetics studies affects their ability to understand the central role of proteins in the mechanisms by which genes determine traits.

\section{DISCUSSION}

Nonmechanistic Conceptions of Genetic Phenomena Are Already Predominant among Students at the Beginning of Their Genetics Studies in School

It has been shown that students are familiar with some genetic concepts before their genetics studies (Nelkin et al., 1997; Venville et al., 2005; Venville and Donovan, 2007). The fact that some students begin their genetics studies with a certain conception of genetic concepts suggests that this conception might be, at least in some cases, scientifically wrong. In this study, we characterized two types of conceptions of genetic phenomena: mechanistic and nonmechanistic. In both cases, the conception is that genes are related to traits. The difference is that the mechanistic conception suggests that genes affect traits. Describing genes as affecting traits does not account for a mechanistic explanation, but it does describe the causal relationship between genes and traits, thereby providing the need for a mechanism (Craver and Darden, 2013). The nonmechanistic type of conception is that genes are synonymous to traits or that genes are trait-bearing particles, as previously reported (Lewis and Kattmann, 2004; Venville et al., 2005). These two conceptions depict the relationship between genes and traits in a nonmechanistic manner because they do not reflect the need for a mechanism.

We found that nonmechanistic conceptions are common among students before their genetics studies. One-third of ninth-grade students who were at the beginning of their first genetics course in school described the relationships between genes and traits in a nonmechanistic manner. Among the other students, one-third held a mechanistic conception. We found almost the same proportion of nonmechanistic conceptions in a class of 12 th-grade students. This suggests that these nonmechanistic conceptions are established before formal genetics education and may continue to be held by the students during their advanced studies.

\section{Nonmechanistic Conceptions of Genetic Phenomena Affect Students' Ability to Learn Genetic Mechanisms}

Lewis and Kattmann (2004) raised the possibility that, because nonmechanistic conceptions abolish the need for a mechanism, they might form a barrier to learning such mechanisms. Moreover, it has been suggested that ideas that are acquired through learning, but that cannot be integrated with prior knowledge into a coherent idea, are isolated and forgotten (Ausubel, 1963; Linn and Eylon, 2011). We thus hypothesized a dependence between holding a nonmechanistic conception and the ability to learn the mechanisms by which genes affect traits.

We found that, in both ninth and 12th grades, students holding nonmechanistic conceptions of the relationship between genes and traits were less successful in learning the mediating mechanisms involving proteins than other students. Although they underwent instruction that is specifically designed to target the function of proteins as mediators, these students did not seem to understand the centrality of proteins in providing explanations for genetic phenomena. On the other hand, students who held a mechanistic conception regarding the gene-trait relationship before instruction understood the centrality of proteins after instruction. We showed that these differences in learning ability apply only to learning the genetic mechanisms by which genes determine traits and not to learning other genetic issues, such as structural relationships between concepts.

We suggest that the reason for this barrier to learning these mechanisms is the inability to connect new knowledge about proteins into nonmechanistic conceptions of the relationships between genes and trait. This suggestion is based on the knowledge integration (KI) perspective, according to which students form connections between ideas: some are spontaneous and temporary, and some are stable (Clark and Linn, 2013). KI motivates students to recognize gaps between ideas and to seek ways to fill them (Linn and Eylon, 2011). Students who conceive of genes as traits or trait-bearing particles may not be able to identify a mechanistic gap in their knowledge; therefore, one can assume that the role of proteins cannot be coherently incorporated into their prior conceptions and will be isolated and forgotten (following Linn and Eylon, 2011).

Our results suggest that focusing on proteins as mediators between genes and traits is important for a mechanistic understanding of genetics (Duncan et al., 2009; Duncan and Tseng, 2011; Gericke and Smith, 2014; Todd and Kenyon, 2015); however, it is not sufficient. These results may explain, at least in part, why not all students benefit from mechanism-centered instruction and continue to have difficulties explaining genetic phenomena (Duncan et al., 2011; Freidenreich et al., 2011; Reinagel and Speth, 2016; Haskel-Ittah and Yarden, 2017). Our results suggest that one of the factors leading to these differences is the conception of the relationships between genes and traits. This means that genetic mechanisms are difficult to learn not only because of some intrinsic factors of the domain, such as the fact that most concepts are invisible to the naked eye or the multidisciplinary knowledge it requires (Marbach-Ad and Stavy, 2000; Duncan et al., 2009), but also because of their subjective origin, which is dependent on students' conception of genetic phenomena. Future studies should characterize more factors that may lead to such difficulties. These characterizations may enable providing tools for personalized teaching and learning.

\section{The Importance of Correctly Describing the Target Phenomenon}

Russ et al. (2008) developed a framework for mechanistic reasoning that draws on the definition of a mechanism from Machamer et al. (2000). This framework offers a coding scheme for mechanistic reasoning that is composed of seven hierarchically ordered categories. Although this hierarchy considers a logical connection between categories, it is hypothetical and based on the authors' intuition. According to Russ et al. (2008), the first category is "describing the target phenomenon." Our results support the assumption that a description of the target phenomenon should be the first step in mechanistic reasoning. As we showed, many students described genetic phenomena in a nonmechanistic manner, and this perception might inhibit their progress in learning genetic mechanisms. This suggests 
that, without a mechanistic description of the phenomenon, one cannot move toward an understanding of other aspects of the mechanism.

It has been shown that teachers' phrasing sometime implies a nonmechanistic description of the phenomenon. Thörne et al. (2013) performed a linguistic analysis of teachers' discourse during genetics classes and revealed that they sometimes use the terms "genes" and "traits" interchangeably (Thörne et al., 2013). This type of wording may imply that genes and traits are synonymous. In view of our results, the risk in that lies not only in confusing the learner and developing scientifically incorrect conceptions; this incorrect description of genetic phenomena may also lead to the formation of a barrier to learning gene-totrait mechanisms.

\section{Implications for Teaching and Learning}

Our findings suggest a tight dependency between students' conception of the relation between genes and traits and their ability to learn its underlying mechanisms. The KI perspective describes learners as holding various, occasionally isolated ideas about scientific issues. These ideas sometimes contradict scientifically normative views. This perspective argues that ignoring those contradictory ideas may result in isolating scientifically normative ideas from the students' prior knowledge and suggests that isolated ideas may eventually be ignored or forgotten. Thus, KI places the emphasis on respecting these ideas and building on them to ensure that new and old ideas will be compared, modified, and integrated in a coherent manner (Linn and Eylon, 2011).

It has been shown that, to form an integrated model of genetics, students should be able to form connections between concepts in a coherent manner (Marbach-Ad, 2001; Gericke and Wahlberg, 2013). Our results suggest that the concept "protein" cannot be integrated into a nonmechanistic conceptual model of genetics. According to these findings, we suggest that students' conception of the relationship between genes and traits be classified before teaching the underlying mechanisms. Students with a nonmechanistic conception should first undergo instruction that promotes reconstruction of the connection between genes and traits and assists in finding a mechanistic gap; only then can they learn genetic mechanisms. The efficiency of such instruction remains to be determined.

Duncan et al. (2009) offered an LP for learning genetics. This LP is based on basic ideas whose complexity is presented gradually. One of these ideas (referred to in the LP as "construct B") deals with the concept of genes as instructions. This idea was refined to include six levels of understanding (Shea and Duncan, 2013; Todd and Kenyon, 2015). Lower levels refer to genes as determining traits or affecting the body, midlevels refer to genes as instructions for biological entities and, at the higher levels, instructions for proteins. Another idea (construct C) deals with proteins as central functional entities in cells that connect genes and traits. The higher levels of this construct deal with proteins as central in connecting genes and traits, while the lower levels deal with proteins in a more general manner that is disconnected from traits or genes.

When this LP was developed, it did not include any hypotheses regarding dependencies between constructs. Shea and Duncan (2013) examined contingencies between constructs B and $\mathrm{C}$. They found that the ideas presented by constructs $\mathrm{B}$ and
C could be integrated to allow reasoning only when level 4 was reached in construct $B$ (understanding that genes are instructions for molecules) and level 3 was reached in construct $\mathrm{C}$ (understanding that proteins are functional).

The present study suggests that this contingency is due to the fact that, as long as students conceive of genes as noninstructional or as instructions for the trait itself, they do not have the need for a mechanism and thus probably will not integrate ideas about genes with ideas about proteins. This implies that ideas regarding proteins in construct $\mathrm{C}$ should be learned only after reaching levels of higher sophistication (4 or higher) in construct B; otherwise, ideas about proteins will not be integrated into a coherent idea with the concept of genes and thus will be forgotten (Linn and Eylon, 2011). The splitting of this construct into "proteins do the work of the cell" and "proteins are the mechanism that connects genes and traits," as suggested by Todd and Kenyon (2015), is also supported because these two ideas may be integrated coherently only after understanding the mechanistic relationships between genes and traits.

One limitation of this study is the small number of students participating in the pretest and posttest parts of the study. These two small groups of ninth and 12th graders were not meant to represent the whole population, but they do reflect a trend in both age groups. In addition, our analysis led to clear-cut results from which our conclusions arise in a straightforward manner. Another limitation of this study is that inferences to students' cognitive understanding were strictly based on concept maps and open-ended questions. A deeper understanding of the characterized conceptions and the levels of mechanistic understanding remain to be determined in future studies.

In conclusion, this work describes how conceiving a phenomenon in a nonmechanistic manner may disrupt the learning of the mechanism underlying the phenomenon. This result suggests that characterizing the phenomenon is a crucial step in learning the mechanism. One cannot move forward to learn the mechanism underlying a phenomenon that has been described as nonmechanistic, namely, a phenomenon that is conceived as having no intermediating mechanism. The fact that students have some knowledge about natural phenomena before learning about them in school suggests that at least some students may have nonmechanistic conceptions of these phenomena. According to our findings, it is highly important that these nonmechanistic conceptions be identified and dealt with before teaching the underlying mechanism. The question that still remains is which interventions will assist students in shifting their conception of phenomena toward a more mechanistic one.

\section{ACKNOWLEDGMENTS}

This work was supported by the Rothschild-Weizmann Program for Excellence in Science Education and by a postdoctoral fellowship from the dean of the Department of Science Teaching at the Weizmann Institute of Science. We thank the teachers and students who participated in this study and Ziv Ariely for the graphic design. We thank the members of our group for fruitful discussions.

\section{REFERENCES}

Abrams, E., \& Southerland, S. (2001). The how's and why's of biological change: How learners neglect physical mechanisms in their search for meaning. International Journal of Science Education, 23(12), 1271-1281. 
Ausubel, D. G. (1963). Cognitive structure and the facilitation of meaningful verbal learning 1. Journal of Teacher Education, 14(2), 217-222.

Boogerd, F. C., Bruggeman, F. J., Richardson, R. C., Stephan, A., \& Westerhoff, H. V. (2005). Emergence and its place in nature: A case study of biochemical networks. Synthese, 145(1), 131-164.

Clark, D. B., \& Linn, M. C. (2013). The knowledge integration perspective: Connections across research and education. In Vosniadou, S. (Ed.), International handbook of research on conceptual change (pp. 520-538). New York: Routledge.

Craver, C. F. (2001). Role functions, mechanisms, and hierarchy. Philosophy of Science, 68(1), 53-74.

Craver, C. F. (2006). When mechanistic models explain. Synthese, 153(3) $355-376$.

Craver, C. F., \& Darden, L. (2013). In search of mechanisms: Discoveries across the life sciences. Chicago: University of Chicago Press.

Darden, L. (2008). Thinking again about biological mechanisms. Philosophy of Science, 75(5), 958-969.

Dos Santos, V. C., Joaquim, L. M., \& El-Hani, C. N. (2012). Hybrid deterministic views about genes in biology textbooks: A key problem in genetics teaching. Science \& Education, 21(4), 543-578.

Duncan, R. G., Freidenreich, H. B., Chinn, C. A., \& Bausch, A. (2011). Promoting middle school students' understandings of molecular genetics. Research in Science Education, 41(2), 147-167

Duncan, R. G., \& Reiser, B. J. (2007). Reasoning across ontologically distinct levels: Students' understandings of molecular genetics. Journal of Research in Science Teaching, 44(7), 938-959.

Duncan, R. G., Rogat, A. D., \& Yarden, A. (2009). A learning progression for deepening students' understandings of modern genetics across the 5 th-10th grades. Journal of Research in Science Teaching, 46(6), 655674

Duncan, R. G., \& Tseng, K. A. (2011). Designing project-based instruction to foster generative and mechanistic understandings in genetics. Science Education, 95(1), 21-56.

Flodin, V. S. (2009). The necessity of making visible concepts with multiple meanings in science education: The use of the gene concept in a biology textbook. Science \& Education, 18(1), 73-94

Freidenreich, H. B., Duncan, R. G., \& Shea, N. (2011). Exploring middle school students' understanding of three conceptual models in genetics. International Journal of Science Education, 33(17), 2323-2349.

Gericke, N., \& Hagberg, M. (2007). Definition of historical models of gene function and their relation to students' understanding of genetics. Science \& Education, 16(7-8), 849-881.

Gericke, N., Hagberg, M., \& Jorde, D. (2013). Upper secondary students understanding of the use of multiple models in biology textbooks-The importance of conceptual variation and incommensurability. Research in Science Education, 43(2), 755-780.

Gericke, N., \& Smith, M. U. (2014). Twenty-first-century genetics and genomics: Contributions of HPS-informed research and pedagogy. In Matthews, M. R. (Ed.), International handbook of research in history, philosophy and science teaching (pp. 423-467). Dordrecht, Netherlands Springer.

Gericke, N., \& Wahlberg, S. (2013). Clusters of concepts in molecular genetics: A study of Swedish upper secondary science students understanding. Journal of Biological Education, 47(2), 73-83.

Haskel-Ittah, M., \& Yarden, A. (2017). Toward bridging the mechanistic gap between genes and traits by emphasizing the role of proteins in a computational environment. Science \& Education, 26(10), 143-1160.

Lewis, J., \& Kattmann, U. (2004). Traits, genes, particles and information: Re-visiting students' understandings of genetics. International Journal of Science Education, 26(2), 195-206

Linn, M. C., \& Eylon, B.-S. (2011). Science learning and instruction: Taking advantage of technology to promote knowledge integration. New York: Routledge.
Machamer, P., Darden, L., \& Craver, C. F. (2000). Thinking about mechanisms. Philosophy of Science, 67(1), 1-25.

Marbach-Ad, G. (2001). Attempting to break the code in student comprehension of genetic concepts. Journal of Biological Education, 35(4) 183-189.

Marbach-Ad, G., \& Stavy, R. (2000). Students' cellular and molecular explanations of genetic phenomena. Journal of Biological Education, 34(4), 200-205.

Nelkin, D., Lindee, M. S., \& Ashkenas, J. (1997). The DNA mystique: The gene as a cultural icon. American Journal of Human Genetics, 60(1), 248.

Novak, J. D., \& Gowin, D. B. (1984). Learning how to learn. Cambridge, UK: Cambridge University Press.

Reinagel, A., \& Speth, E. B. (2016). Beyond the central dogma: Model-based learning of how genes determine phenotypes. CBE-Life Sciences Education, 15(1), ar4

Russ, R. S., Scherr, R. E., Hammer, D., \& Mikeska, J. (2008). Recognizing mechanistic reasoning in student scientific inquiry: A framework for discourse analysis developed from philosophy of science. Science Education, 92(3), 499-525.

Shea, N. A., \& Duncan, R. G. (2013). From theory to data: The process of refining learning progressions. Journal of the Learning Sciences, 22(1), 7-32.

Shea, N. A., Duncan, R. G., \& Stephenson, C. (2015). A tri-part model for genetics literacy: Exploring undergraduate student reasoning about authentic genetics dilemmas. Research in Science Education, 45(4), 485-507.

Southard, K., Wince, T., Meddleton, S., \& Bolger, M. S. (2016). Features of knowledge building in biology: Understanding undergraduate students ideas about molecular mechanisms. CBE-Life Sciences Education, 15(1) ar7.

Stewart, J., Cartier, J. L., \& Passmore, C. M. (2005). Developing understanding through model-based inquiry. In How students learn: Science in the classroom (pp. 515-565). Washington, DC: The National Academies Press.

Tamir, P., \& Zohar, A. (1991). Anthropomorphism and teleology in reasoning about biological phenomena. Science Education, 75(1), 57-67.

Thörne, K., \& Gericke, N. (2014). Teaching genetics in secondary classrooms A linguistic analysis of teachers' talk about proteins. Research in Science Education, 44(1), 81-108.

Thörne, K., Gericke, N., \& Hagberg, M. (2013). Linguistic challenges in Mendelian genetics: Teachers' talk in action. Science Education, 97(5), 695722.

Todd, A., \& Kenyon, L. (2015). Empirical refinements of a molecular genetics learning progression: The molecular constructs. Journal of Research in Science Teaching, 53(9), 1385-1418.

van Mil, M. H., Boerwinkel, D. J., \& Waarlo, A. J. (2013). Modelling molecular mechanisms: A framework of scientific reasoning to construct molecular-level explanations for cellular behaviour. Science \& Education, 22(1), 93-118.

van Mil, M. H., Postma, P. A., Boerwinkel, D. J., Klaassen, K., \& Waarlo, A. J (2016). Molecular mechanistic reasoning: Toward bridging the gap between the molecular and cellular levels in life science education. Science Education, 100(3), 517-585.

Venville, G., \& Donovan, J. (2007). Developing year 2 students' theory of biology with concepts of the gene and DNA. International Journal of Science Education, 29(9), 1111-1131.

Venville, G., Gribble, S. J., \& Donovan, J. (2005). An exploration of young children's understandings of genetics concepts from ontological and epistemological perspectives. Science Education, 89(4), 614-633.

Venville, G. J., \& Treagust, D. F. (1998). Exploring conceptual change in genetics using a multidimensional interpretive framework. Journal of Research in Science Teaching, 35(9), 1031-1055.

White, R., \& Gunstone, R. (2014). Probing understanding. London: Falmer Press, Routledge. 